\title{
Does International Financial Reporting Standards (IFRSS) Adoption Affects Banks’ Asset Quality in Nigerian Banks?
}

Gabriel O Abba*, James O Alabede, Ene Okwa and Benedict Soje

Department of Accounting, Federal University, Wukari, Nigeria

\begin{abstract}
Asset quality also known as loan portfolio quality is one of the critical areas in determining the overall financial wellness of a bank. Prior to the adoption of IFRS, the Statement of Accounting Standards (SAS 10) and the prudential guideline recognized and specified the measurement criteria for loan portfolios disclosed in the financial statements of Nigerian deposit money banks. With the mandatory adoption of IFRS in Nigeria, a different measurement basis was introduced (IAS 39 and IFRS 9). Thus, this study examines the effect of IFRS adoption on the overall asset quality of Nigerian money deposit banks. The study, which covers the period between 2006 and 2015, applies Generalized Least Square technique to compare the asset quality of banks listed on the Nigerian Stock Exchange before and after the adoption of IFRS. The study reveals that IFRS adoption has significantly affected asset quality of Nigerian banks. It is recommended that deposit money banks should continually strengthen their credit risk management and reporting mechanisms as enshrined in IFRS as this would guarantee good asset quality position in the reported financial statements.
\end{abstract}

Keywords: Asset quality; IFRS; SAS; Non-performing loan

\section{Introduction}

Nigerian economy is the largest economy in Africa with a GDP of over $\$ 500$ billion and one of the emerging-market economies in the world. As a result of the enormous potentials of the economy in terms of market, raw materials, young demographics, among others, the Nigerian economy was identified with three other economies with similar features from which the acronym "MINT" was coined. MINT is an acronym referring to the economies of Mexico, Indonesia, Nigeria, and Turkey [1]. The term was originally coined by Fidelity Investments, a Boston-based asset management firm, and was popularized by Jim O'Neill of Goldman Sachs. The term is primarily used in the economic and financial spheres as well as in academia.

One of the key factors that earned Nigeria recognition and inclusion in the MINT economies is its emerging financial market. However, prior to the popular MINT acronym, the financial sector of Nigeria was bedevilled with the aftermath of the global economic meltdown and huge presence of toxic assets in banks' balance sheets. The increasing level of bad loans eroded asset quality with a multiplier effect on profitability, capital adequacy ratio and the ability of banks to lend to the real sector of the economy for growth and development. This prompted the Central Bank of Nigeria (CBN) in 2009 [2] to sanitize the banking system through various means, one of which is tightening of regulation on Asset Quality Ratio (AQR) of deposit money banks in Nigeria and the adoption of International Financial Reporting Standards (IFRSs). Prior to the adoption of IFRS, the Statement of Accounting Standards (SAS 10) and the prudential guideline recognized and specified the measurement criteria for loan portfolios disclosed in the financial statements of Nigerian deposit money banks. With the mandatory adoption of International Financial Reporting Standards in Nigeria, a different measurement basis was introduced (IAS 39 and IFRS 9) for the measurement and recognition of asset quality.

Asset Quality Ratio (AQR) also referred to as Non-performing Loan Ratio (NPR) is measured by the ratio of total non-performing loans to total loans and advances [3]. The ratio can also be computed as the ratio of total non-performing loans to total assets of a bank. According to the International Monetary Fund [4], a non- performing loan is any loan in which interest and principal payments are more than 90 days overdue; or more than 90 days worth of interest has been refinanced. On the other hand the Basel Committe [5] puts non-performing loans as loans left unpaid for a period of 90 days. Thus time is an essential factor in deciding whether or not the quality of a loan facility is eroded. It should be noted that the higher the Asset Quality Ratio, the lower the financial health of banks loans and advances portfolio and vice versa.

The problem of poor Asset Quality Ratio position has been a challenge for the Nigerian apex bank with the bank pegging a healthy Asset Quality Ratio position for any bank at a maximum of $5 \%$. However, Nigeria's banking sector Non-Performing Loans Ratio (Asset Quality Ratio) rose to about $10.1 \%$ as at April 2016, as disclosed by the Deputy Governor of the Central Bank of Nigeria, Mrs Sarah Alade. The rise in the Non-Performing Loans Ratio is said to be well above the prudential limit of five per cent as enshrined in the CBN prudential guidelines for deposit money banks in Nigeria.

The magnitude of non-performing loans in Nigeria increased from about $\$ 0.3$ billion in 1981 to about $\$ 5$ billion in 1987. The total nonperforming loans increased to about $\$ 112$ billion in 2000 and further to about 1.1 trillion in 2011 [6]. This rising trend in non-performing loans and its attendant negative consequences necessitated the CBN to introduce an improved prudential guideline which focuses on measures to check the rising trend of bad loans which affect the asset quality of banks. To further improve the asset quality of Nigerian deposit money banks, the prudential guidelines established the foundation for smooth transition to IFRSs.

The year 2010 was the year of transition to IFRS for all deposit

*Corresponding author: Gabriel O Abba, Department of Accounting Federal University Wukari, Wukari, Nigeria, Tel: +234-8031580589; E-mail: angelgabrielabba@gmail.com

Received April 24, 2018; Accepted May 08, 2018; Published May 17, 2018

Citation: Abba GO, Alabede JO, Okwa E, Soje B (2018) Does International Financial Reporting Standards (IFRSS) Adoption Affects Banks' Asset Quality in Nigerian Banks?. J Account Mark 7: 273. doi: 10.4172/2168-9601.1000273

Copyright: $\odot 2018$ Abba GO, et al. This is an open-access article distributed under the terms of the Creative Commons Attribution License, which permits unrestricted use, distribution, and reproduction in any medium, provided the original author and source are credited. 
money banks in Nigeria. As such the measurement and recognition criteria for loans and advances changed from that enshrined in the prudential guidelines to that of IFRS. The prudential guideline measures loans and advances based on the cost model and recognize loan losses on the anticipated loss model [7]. Specifically, the prudential guideline established general objective and subjective criteria for recognizing and measuring loan loss provisions and the overall asset quality of deposit money banks as follows:

Non-performing credit facilities should be classified into three categories namely: Sub-standard, doubtful or lost on the basis of the objective and the subjective criteria.

For facilities classified as sub-standard, doubtful, or lost:

- Interest overdue by more than 90 days should be suspended and recognized on cash basis only.

- Principal repayments that are over due by more than 90 days should be fully provided for and recognized on cash basis only.

For principal repayments not yet due on non-performing credit facilities, provision should be made as follows:

- Sub-standard credit facilities: $10 \%$ of the outstanding balance;

- Doubtful credit facilities: $50 \%$ of the outstanding balance;

- Lost credit facilities: $100 \%$ of the outstanding balance.

The incurred loss approach of IAS 39 requires banks to make provision only for incurred losses as of the balance sheet date. Also, losses expected as a result of future events may not be recognized [7]. With the adoption of IFRS, loans and receivables are measured initially at fair value. This is usually the same as the fair value of the consideration given. Subsequently, loans and advances are measured at amortized cost using the effective interest method. Also banks are to assess at the end of each reporting period whether there is any objective evidence that financial assets (loans and receivables) measured at amortized cost is impaired. If there is objective evidence that an impairment loss on financial assets measured at amortized cost has been incurred, the amount of the loss is measured as the difference between the asset's carrying amount and the present value of estimated future cash flows (excluding future credit losses that have not been incurred) discounted at the financial asset's original effective interest rate (i.e., the effective interest rate computed at initial recognition). The carrying amount of the asset shall be reduced either directly or through use of an allowance account. The amount of the loss shall also be recognized in profit or loss.

Thus the measurement and recognition criteria for asset quality in the prudential guidelines and IFRSs are completely different in that the prudential guideline adopts the anticipated loss model while IFRS adopts the incurred loss model. The study therefore intends to investigate the extent to which the mandatory adoption of IFRS's incurred loss model by deposit money banks affects the reported value of non-performing loans and the overall asset quality since 2010 .

\section{Review of Related Literature}

Since asset quality has been an issue of concern for financial sector regulators as well as deposit money banks the world over, the subject matter has attracted attention in the academia with several literature contributing to knowledge on its determinants; its impact on performance and capital adequacy as well as measurement and recognition issues. To further ensure healthy asset quality position, deposit money banks now adopt IFRS recognition and measurement criteria. The question therefore arises as: "to what extent does the adoption of IFRS affect asset quality of deposit money banks in Nigeria?"

Generally, several literatures have come up with different findings on the impact of IFRS on information disclosed on the financial statement. Zeghal et al., [8]; Arum [9]; Wan Ismail et al., [10]; Liu et al., [11]; Iatridis [12]; Lin et al., among others established that IFRS adoption is associated with high accounting quality [13]. Nevertheless, Ames [14]; Lin et al., [15]; Paglietti [16]; Paananen and Lin [17] discard the assertion that IFRS adoption is associated with high accounting quality. However, this study focuses on one of the elements of in deposit money banks' financial statement which is loans and receivables.

Eneje et al. [7] is one of the most recent studies on the impact of IFRS adoption on asset quality of deposit money banks in Nigeria. The study specifically investigated the effect of IFRS adoption on the mechanics of loan loss provisioning for Nigerian banks using an ex post facto research design and data from the twenty two banks in the industry for eleven years study period. The study also found that the application of stricter impairment rules reduces discretion in the main operating accrual in banks' accounts and the loan loss provision during the IFRS era. Also based on the sampled bank dataset and results, the study revealed that the adoption of IFRS has had significant effects on the mechanics of loan loss provisioning in Nigerian money deposit banks. However, the study did not clearly reveal the extent to which Asset Quality Ratio has been affected by the adoption of stricter rules in IFRS. Asset quality still remains a problem in Nigeria that the apex regulator is grappling with.

Onalo et al. [18] conducted an extensive study on the impact of IFRS on the quality of Nigerian banks' financial statements. Among other key findings from the study, the authors also concluded based on the results that credit quality (also referred to as asset quality) is higher for the IFRS reporting era compared to the local GAAP reporting era (the prudential guideline anticipated loss model). The results reveal substantial decrease in the amount of non-performing Loans generated by a particular amount of total loan following the adoption of IFRS. However, the period for the study is considered inadequate as only six years [three years each for the pre- and post-adoption periods] was used for the study i.e., 2008-2013. The study did not also focus on the Asset Quality Ratio which is the overall measure of wellness of loans and advances in banks' balance sheet.

Firoz et al., [19] examined the impact of IFRS generally on the Indian banking industry after implementation in April, 2011 using qualitative research approach and based on critical analysis of published financial statements. Specifically, the paper is based upon the critical analysis of prudential issues in the financial statements of the Indian banking industry, such as business per employee, capital and reserves, investments and advances and net non-performing assets ratios (also referred to as Asset Quality Ratio). The study concludes that the implementation of IFRS shall have major impact over the advances, financial instruments and investments of Indian banks. The study also observed that the industry requires a detailed analysis and valuation of existing advances and all other instruments in compliances with the IFRS. Although, the findings of the study are in line with Eneje and Obidike [7] and Onalo et al., [18] the period was too short for sufficient evidence to be obtained on the impact of IFRS on recognition and measurement of loans and receivables. Also the qualitative approach adopted in the study was not robust enough. 
Furthermore, Ozili [20] examined whether or not IFRS matters in loan loss provisioning, income smoothing, signaling, capital management and procyclicality. The study adopted a panel-data regression with fixed effects after controlling for Basel Regulation. Overall, the study finds evidence to indicate that Nigerian banks use Loan Loss Provisions to manage capital, smooth reported earnings and signal loan quality in the post-IFRS period. Thus, the findings indicate that, during IFRS reporting periods, reported earnings and related accounting numbers do not truly reflect the underlying economic reality of Nigerian deposit money banks. Although, the study used loan loss provisions (LLP) as its dependent variable, it does not clearly show the effect of IFRS on the overall Asset Quality Ratio (which is different from loan loss provision) of deposit money banks in Nigeria.

Gebhardt and Novotny-Farkas [21] examined the implications of mandatory IFRS adoption on the accounting quality of banks in twelve EU countries. Specifically, the study analyzed how the change in the recognition and measurement of banks' main operating accrual items and loan loss provisioning affect income smoothing behaviour and timely loss recognition. They found out that restriction to recognize only incurred losses under IAS 39 significantly reduces income smoothing. This effect is less pronounced in countries with stricter bank supervision, widely dispersed bank ownership and for EU banks crosslisted in the US. They also observed that application of the incurred loss approach results in less timely loan loss recognition implying delayed recognition of future expected losses.

\section{Methodology}

The study adopts descriptive and correlational research designs and applies the Generalized Least Square (GLS) technique of data analysis for the ten-year period, 2006 to 2015. The data for the study can be described as panel data as it was obtained from financial statements of the 16 listed deposit money banks in Nigeria for ten-year (10) period with the first five years (2006 to 2010) as the pre-IFRS adoption period and the next five years (2011 to 2015) as the post-IFRS adoption period.

Generalized Least Square technique of data analysis was adopted to address challenges that may be posed by heteroskedasticity and autocorrelation. Descriptive statistics and correlation analysis was also carried out on the panel data. The variables for the study are defined in the Table 1.

The following model has been developed for the study:

$$
A Q R_{\text {it }}=\beta_{0}+\beta_{1} \mathrm{ROA}_{\mathrm{it}}+\beta_{2} \mathrm{CAR}_{\mathrm{it}}+\beta_{3} \mathrm{IFRS}_{\mathrm{t}}+\varepsilon_{\mathrm{it}}
$$

Where: $\mathrm{AQR}_{\mathrm{it}}$ : Assets Quality Ratio of bank I; at a period t; $\mathrm{ROA}_{\mathrm{it}}$; Returns on Assets of bank $i$ at a period t; $\mathrm{CAR}_{\mathrm{it}}$ : Capital Adequacy Ratio of bank $i$ at a period t; IFRS: Lending rate at a period $t ; \beta_{0}$ : Intercept; $\beta_{1-3}$ : Coefficient of the independent variables.

\section{Results and Discussion of Findings}

The results of the descriptive statistics and the multiple linear regression analysis using OLS and GLS were presented in Tables 2-4 and discussed in the section (Appendices 1-6).

\section{Descriptive statistics}

The results of the descriptive statistics in Table 2 explicitly show the position of the Nigerian deposit money banks in terms of key prudential matrices before and after adoption of IFRS. Asset Quality Ratio which measures the financial health of loans and advances on banks' balance sheet is better in the post IFRS period with an improvement from about $19 \%$ in the pre-IFRS period to about $6 \%$ in the post-IFRS period. To further corroborate this position, the standard deviation in the post-IFRS adoption period for Asset Quality Ratio is smaller than the standard deviation in the pre-IFRS era. In the post-IFRS era, the standard deviation which measures the average dispersion of observations from the mean is about $3 \%$ showing that observed individual Asset Quality Ratios in the post-IFRS era are on the average 3\% dispersed around the mean of the same era. Observations on asset quality in the pre-IFRS era on the other hand, reveal high dispersion around the mean with a standard deviation of about $67 \%$. Profitability in the post-IFRS adoption era has also improved from about $2 \%$ in the pre-IFRS period to about $3 \%$ in the post-IFRS period. CAR which is a measure of the overall wellness and soundness of banks has also improved from about $26 \%$ in the pre-IFRS period to about $31 \%$ in the post-IFRS period. Therefore, based on the results of the descriptive statistics, it is observed that IFRS adoption has impacted on

\begin{tabular}{|c|c|c|}
\hline \multicolumn{2}{|l|}{ Variables } & \multirow{2}{*}{$\begin{array}{l}\text { Definition } \\
\frac{\text { Total Non - performing Loans }}{\text { Gross Loan }}\end{array}$} \\
\hline Dependent variable & Asset Quality Ratio (AQR) & \\
\hline Independent variable & IFRS & Dummy Variable ['0' for Pre-IFRS Adoption Period and '1' for Post-IFRS adoption period] \\
\hline \multirow[t]{2}{*}{ Control variables } & Returns on Assets (ROA) & $\begin{array}{l}\frac{\text { Annual Earnings }}{\text { Total Assets }} \\
=\frac{\text { Net Profit }}{\text { Total Assets }}\end{array}$ \\
\hline & Capital Adequacy Ratio (CAR) & $\begin{array}{l}\frac{\text { Total Qualifying Capital }}{\text { Total Risk }- \text { weighted Asset }} \\
\text { Total Qualifying Capital }=1^{\text {st }} \text { Tier capital+2 }{ }^{\text {nd }} \text { Tier capital }\end{array}$ \\
\hline
\end{tabular}

Table 1: Variables measurement.

\begin{tabular}{|c|c|c|c|c|c|c|c|c|}
\hline \multicolumn{5}{|c|}{ Pre-IFRS Adoption (2006-2010) } & \multicolumn{4}{|c|}{ Post-IFRS Adoption (2011-2015) } \\
\hline Variable & Mean & Standard deviation & Minimum & Maximum & Mean & Standard deviation & Minimum & Maximum \\
\hline AQR & 0.19 & 0.67 & 0.04 & 0.3 & 0.06 & 0.03 & 0.01 & 0.14 \\
\hline ROA & 0.02 & 0.01 & 0 & 0.04 & 0.03 & 0.01 & -0.03 & 0.05 \\
\hline CAR & 0.2677 & 0.0503 & 0.17 & 0.45 & 0.31 & 0.08 & 0.16 & 0.49 \\
\hline Observations & \multicolumn{4}{|c|}{60} & \multicolumn{4}{|c|}{60} \\
\hline
\end{tabular}

Table 2: Descriptive statistics of dependent and independent variables. 
key banking sector performance matrices as contained in prudential guidelines of the Central Bank of Nigeria (CBN).

\section{Correlation analysis}

Observing the pattern of the Pearson Product Moment correlation coefficients in Table 3 , the result reveals a high and significant negative correlation between AQR and IFRS. With a correlation coefficient of about -0.78 , this reveals that continuous adoption and improvement of the various IFRSs would reduce AQR, thus enhancing the overall position of risky financial assets such as loans and advances in banks' balance sheet. Also, the correlation coefficient reveals positive relationships between IFRS, ROA and CAR. With the adoption of IFRS, profitability which is measured by ROA and capital adequacy has significantly improved. The results of the correlation matrix agree with the overall position of the descriptive statistics which also shows significant improvement in the key prudential ratios adopted in the study.

\section{Regression results and interpretation}

The multiple regression results for GLS and OLS reveal the same figures for the beta coefficients and the levels of significance (Table 4). On the other hand, the multiple regression results for the OLS reveal that the coefficient of determination represented by $\mathrm{R}^{2}$, is about 0.61 with an adjusted $\mathrm{R}^{2}$ of about 0.60 . This shows that about $61 \%$ of total variation in Asset Quality Ratio of Nigerian deposit money banks is caused by changes profitability, represented by return on assets, quality of bank capital, resented by capital adequacy ratio and the adoption of IFRS. Also, the high value of $\mathrm{R}^{2}$ means that the estimated model has good and high forecasting power, since only about $39 \%$ of the variations in Asset Quality Ratio were left unaccounted for by the model, hence captured by the error term $\xi$. This shows that the model is fit and robust and the independent variables are well selected, combined and used [22].

\begin{tabular}{|c|c|c|c|c|}
\hline Variables & AQR & ROA & CAR & IFRS \\
\hline AQR & 1.0000 & & & \\
\hline ROA & -0.2973 & 1.0000 & & \\
\hline CAR & -0.3264 & 0.4565 & 1.0000 & \\
\hline IFRS & -0.7753 & 0.3105 & 0.2995 & 1.0000 \\
\hline
\end{tabular}

Table 3: Correlation matrix.

\begin{tabular}{|c|c|c|c|c|}
\hline \multicolumn{2}{|c|}{ Statistics } & \multirow{2}{*}{$\begin{array}{c}\text { Beta } \\
\text { coefficients }\end{array}$} & \multirow[t]{2}{*}{ t-Values } & \multirow[t]{2}{*}{ Significance } \\
\hline OLS Results & Variables & & & \\
\hline & ROA & -0.1570 & -0.38 & 0.707 \\
\hline & CAR & -0.1113 & -1.41 & 0.161 \\
\hline & IFRS & -0.1196 & -11.93 & 0.000 \\
\hline \multicolumn{2}{|c|}{$\mathrm{R}^{2}$} & \multicolumn{3}{|c|}{0.6113} \\
\hline \multicolumn{2}{|c|}{ Adjusted $\mathrm{R}^{2}$} & \multicolumn{3}{|c|}{0.6012} \\
\hline \multicolumn{2}{|c|}{ F-Statistic } & \multicolumn{3}{|c|}{60.80} \\
\hline \multicolumn{2}{|c|}{ Significance } & \multicolumn{3}{|c|}{0.0000} \\
\hline \multirow[t]{6}{*}{ GLS Results } & Variables & $\begin{array}{c}\text { Beta } \\
\text { coefficients }\end{array}$ & Z-Values & Significance \\
\hline & ROA & -0.1570 & -0.38 & 0.702 \\
\hline & CAR & -0.1113 & -1.44 & 0.151 \\
\hline & IFRS & -0.1196 & -12.13 & 0.000 \\
\hline & Wald Chi2 (3) & 188.69 & & \\
\hline & $\begin{array}{l}\text { Number of } \\
\text { observations }\end{array}$ & \multicolumn{3}{|c|}{120} \\
\hline
\end{tabular}

Table 4: Stata 11 regression results for Generalized Least Square (GLS) and Ordinary Least Square (OLS) model.
The GLS result reveals absence of heteroskedasticity and autocorrelation. Just as the results of the descriptive statistics and the correlation matrix, the regression results also reveal that IFRS adoption negatively affects Asset Quality Ratio of deposit money banks in Nigeria. For every period of IFRS adoption, asset quality position improved by about $12 \%$. This result is consistent with Eneje and Obidike [7], Onalo et al., [18] and Firoz et al., [19]. However, the result is contrary to the findings of Ozili [20]. The multiple regression coefficients of ROA and CAR are also negative but not significant at any level. This does not pose any problem to the study since ROA and CAR are control variables.

This therefore reveals that the adoption of IFRS and its inclusion in the CBN prudential guideline has significantly affected measurement and recognition of loans and advances as well as loan loss provisions. Also, the adoption of IFRS by deposit money banks appears to have strengthened credit risk management practices as contained in IAS 39 and IFRS 9.

\section{Conclusion and Recommendations}

The research is an attempt to answer the question as whether IFRS adoption affects loan portfolio quality of deposit money banks in $\mathrm{Ni}$ geria. Drawing from empirical literature reviewed and results of the multiple regression analysis using GLS, the study concludes that IFRS adoption significantly affects Asset Quality Ratio of Nigerian Deposit Money Banks. The study also concludes that significant improvement has been recorded in the key micro prudential ratios of deposit money banks since the adoption of IFRS. Thus, the apex regulator of the Nigerian banking sector should improve on its banking supervision role to ensure optimal compliance with relevant IFRSs as it relates to credit management and overall asset quality of deposit money banks in $\mathrm{Ni}$ geria. Also, deposit money banks should continually strengthen their credit risk management and reporting mechanisms as enshrined in the relevant IFRSs as this would guarantee good asset quality position in the reported financial statements.

\section{References}

1. Nkusu MM (2011) Nonperforming loans and macro-financial vulnerabilities in advanced economies. International Monetary Fund.

2. CBN (2010) The prudential guidelines for licensed banks. Lagos. CBN Publications.

3. Mayes D, Stremmel H (2012) The effectiveness of capital adequacy measures in predicting bank distress.

4. International Monetary Fund Annual Report (2009) International Monetary Fund.

5. Basel Committee (2001) BIS

6. Akinlo O, Emmanuel M (2014) Determinants of non-performing loans in Nigeria. Accounting and Taxation 6: 21.

7. Eneje B, Obidike C, Chukwujekwu P (2016) The effect of ifrs adoption on the mechanics of loan loss provisioning for Nigerian Banks. IOSR Journal of Business and Management 18: 45-52.

8. Zeghal D, Chtourou SM, Fourati YM (2012) The effect of mandatory adoption of IFRS on earnings quality: Evidence from the European Union. Journal of International Accounting Research 11: 1-25.

9. Arum ED (2013) Implementation of international financial reporting standards (IFRS) and the quality of financial statement information in Indonesia. Research Journal of Finance and Accounting 4: 200-209.

10. Wan Ismail WA, Kamarudin KA, Zijl TV, Dunstan K (2013) Earnings quality and the adoption of IFRS-based accounting standards: Evidence from an emerging market. Asian Review of Accounting 21: 53-73.

11. Liu C, Yao LJ, Hu N, Liu L (2011) The impact of IFRS on accounting quality in 
Citation: Abba GO, Alabede JO, Okwa E, Soje B (2018) Does International Financial Reporting Standards (IFRSS) Adoption Affects Banks' Asset Quality in Nigerian Banks?. J Account Mark 7: 273. doi: 10.4172/2168-9601.1000273

Page 5 of 5

a regulated market: An empirical study of China. J Account Auditing Finance 26: 659-676.

12. latridis G (2010) International Financial Reporting Standards and the quality of financial statement information. International Review of Financial Analysis 19: $193-204$

13. Lin CC, Hua CY, Lin WH, Lee WC (2012) IFRS adoption and financial reporting quality: Taiwan experience. International Journal of Academic Research in Accounting, Finance and Management Sciences 2: 283-292.

14. Ames D (2013) IFRS adoption and accounting quality: The case of South Africa. Journal of Applied Economics and Business Research 3: 154-165.

15. Lin S, Riccardi W, Wang C (2012) Does accounting quality change following a switch from US GAAP to IFRS? Evidence from Germany. J Account Public Policy 31: 641-657

16. Paglietti $P$ (2009) Investigating the effects of the EU mandatory adoption of IFRS on accounting quality: Evidence from Italy. Int J Manag Rev 4: 3 .

17. Paananen M, Lin $H$ (2009) The development of accounting quality of IAS and
IFRS over time: The case of Germany. Journal of International Accounting Research 8: 31-55.

18. Onalo U, Lizam M, Kaseri A, Innocent O (2014) International Financial Reporting Standards and the quality of banks financial statement information: Evidence from an emerging Market-Nigeria. World Academy of Science, Engineering and Technology, International Journal of Economics and Management Engineering.

19. Firoz CM, Ansari AA, Akhtar K (2011) IFRS-impact on Indian banking industry International Journal of Business and Management 6: 277.

20. Ozili P (2015) Loan loss provisioning, income smoothing, signaling, capita management and procyclicality: Does IFRS matter? Empirical evidence from Nigeria.

21. Gebhardt GU, Novotny-Farkas Z (2011) Mandatory IFRS adoption and accounting quality of European banks. J. Bus. Finance Account 38: 289-333.

22. Hassan MK, Bashir AH (2003) Determinants of Islamic banking profitability In10th ERF annual conference, Morocco 7. 